\title{
High gene flow due to pelagic larval dispersal among South Pacific archipelagos in two amphidromous gastropods (Neritomorpha: Neritidae)
}

\author{
ED Crandall, JR Taffel and PH Barber ${ }^{1}$ \\ Department of Biology, Boston University Marine Program, Boston, MA, USA
}

\begin{abstract}
The freshwater stream fauna of tropical oceanic islands is dominated by amphidromous species, whose larvae are transported to the ocean and develop in the plankton before recruiting back to freshwater habitat as juveniles. Because stream habitat is relatively scarce and unstable on oceanic islands, this life history would seem to favor either the retention of larvae to their natal streams, or the ability to delay metamorphosis until new habitat is encountered. To distinguish between these hypotheses, we used population genetic methods to estimate larval dispersal among five South Pacific archipelagos in two amphidromous species of Neritid gastropod (Neritina canalis and Neripteron dilatatus). Sequence data from mitochondrial cytochrome oxidase I (COI) revealed that neither species is genetically structured throughout the Western Pacific, suggesting that their larvae
\end{abstract}

have a pelagic larval duration (PLD) of at least 8 weeks, longer than many marine species. In addition, the two species have recently colonized isolated Central Pacific archipelagos in three independent events. Since colonization, there has been little or no gene flow between the Western and Central Pacific archipelagos in $N$. canalis, and high levels of gene flow across the same region in $N$. dilatatus. Both species show departures from neutrality and recent dates for colonization of the Central Pacific archipelagos, which is consistent with frequent extinction and recolonization of stream populations in this area. Similar results from other amphidromous species suggest that unstable freshwater habitats promote long-distance dispersal capabilities.

Heredity (2010) 104, 563-572; doi:10.1038/hdy.2009.138; published online 21 October 2009

Keywords: Neritina; Neripteron; South Pacific; larval dispersal; amphidromy; habitat instability

\section{Introduction}

The life histories of marine and freshwater animals are generally very different: marine animals often have planktonic larvae that are potentially dispersive (Thorson, 1950), whereas freshwater animals typically develop in benthic or brooded egg capsules, probably to reduce dispersal and downstream loss from adult habitat (Holthuis, 1995; Bohonak and Jenkins, 2003). Notable exceptions to this ontogenetic trend can be found in diadromous species, which may reproduce in fresh water before recruiting to marine habitats (anadromy), or reproduce in the ocean before recruiting to freshwater habitats (catadromy). Amphidromy is a lesser-known type of diadromy that has evolved independently in several families of decapod crustaceans, gastropod mollusks and teleost fishes (Myers, 1949; Holthuis, 1995; McDowall, 2004). Although the adults of amphidromous species live and reproduce in streams, rivers or

Correspondence: Dr ED Crandall, Department of Biological Sciences, Old Dominion University, Norfolk, VA 23529, USA.

E-mail:ecrandal@odu.edu

${ }^{1}$ Current address: Ecology and Evolutionary Biology, University of California Los Angeles, 621 Charles E Young Drive South, Los Angeles, CA 90095, USA

Received 16 November 2008; revised 18 August 2009; accepted 10 September 2009; published online 21 October 2009 estuaries, their planktotrophic larvae are released downstream to the ocean, where marine salinities are required for their successful development (Anger et al., 1990; Diesel and Schuh, 1998; Crandall, 1999; Diele and Simith, 2006). After metamorphosis and recruitment to river mouths, juveniles migrate upstream to freshwater habitats (Schneider and Frost, 1986; Blanco and Scatena, 2005; Torres et al., 2006).

Amphidromous species dominate the fish, decapod and gastropod stream fauna on tropical oceanic islands, most likely because they are the only lotic species capable of regularly colonizing these habitats (Resh and de Szalay, 1995; McDowall, 2004). However, although a community ecologist would view them as freshwater animals (for example, Bandel and Riedel, 1998; Smith et al., 2003), their population ecology may be more similar to that of a marine species, because of their pelagically dispersing larvae. Relatively long pelagic larval durations (PLDs) have been estimated from laboratory cultures of amphidromous gastropod veligers (40-98 days, Holthuis, 1995; Kano, 2006) and the otoliths of amphidromous Galaxiid fishes and gobies (63-266 days, Radtke et al., 1988, 2001; Mcdowall et al., 1994; Hoareau et al., 2007b). These PLDs fall at or above the high end of the range found in the planktotrophic larvae of marine invertebrates (7-293 days, Shanks et al., 2003) and fish ( 20-90 days, Brothers et al., 1983). 
Consistent with this high dispersal potential, genetic structure within high-island archipelagos is low or non-existent in amphidromous Neritid and Neritiliid snails (Hodges and Allendorf, 1998; Myers et al., 2000; Kano and Kase, 2004), as well as in Galaxiid and Sicydiine fishes (Chubb et al., 1998; Waters et al., 2000; Berrebi et al., 2005; Hoareau et al., 2007a), suggesting that populations of amphidromous species are genetically structured at scales similar to fully marine species. In contrast, fully lotic species are frequently genetically structured within watersheds or even within reaches (Bunn and Hughes, 1997; Marten et al., 2006).

Lotic habitats are rare in the South Pacific, occurring only on volcanic islands that are tall enough to generate their own adiabatic rainfall. Given the high levels of larval mortality and the effects of diffusion (Cowen et al., 2000), it seems unlikely that significant numbers of larvae that drifted away from their natal archipelago would be able to find suitable freshwater habitat for settlement. Therefore, local selection for traits that favor selfrecruitment could be particularly strong for amphidromous species (Sponaugle et al., 2002; Strathmann et al., 2002). Consistent with this prediction, Sorensen and Hobson (2005) found that newly recruited amphidromous gobies had stable isotope signatures that were similar to inshore plankton rather than offshore plankton, suggesting that larvae prefer to stay in coastal waters. Similar homing behaviors have been suggested for the larvae of amphidromous shrimp and snails (Benstead et al., 2000; Haynes, 2000). Such larval retention could result in limited realized dispersal and pronounced genetic structure among archipelagos.

However, in addition to their rarity, riverine habitats on oceanic islands are inherently unstable. They are characterized by short overall lengths (generally $<5 \mathrm{~km}$ ), with small catchments, and extremely variable flows (Resh and de Szalay, 1995; Craig, 2003). Climactic fluctuations over the past several million years (Hope, 1996) and the rapid erosion and eventual subsidence of individual islands (Whittaker et al., 2008) ensure that populations in oceanic island streams will be subject to local extinction and re-colonization over evolutionary timescales (Covich, 2006). These processes can be expected to leave a molecular signature in the form of shallow, star-like genealogies (Slatkin and Hudson, 1991), and estimates for colonization events that greatly post-date the formation of each archipelago (Price and Clague, 2002).
Chaotic population dynamics have also been shown to promote the evolution of long-distance dispersal ability (Johnson and Gaines, 1990; Holt and Mcpeek, 1996). As the planktotrophic larvae of amphidromous species must settle in a rare, unstable habitat, they could be selected for the ability to delay metamorphosis and extend their planktonic life indefinitely ('death before dishonor' hypothesis, Bishop et al., 2006, see Elkin and Marshall, 2007 for a numerical model). Such a strategy could result in extremely long-distance dispersal, limiting genetic differentiation among archipelagos.

In this study, we assess mitochondrial genetic variation in two amphidromous snail species from the family Neritidae (Gastropoda: Neritopsina). Neritina canalis (Sowerby, 1825) and Neripteron dilatatus (Lesson, 1830) have planktotrophic larvae, as indicated by the 'D'-shaped initial region of their opercula (Kano, 2006) and probably share an amphidromous common ancestor (Holthuis, 1995). Neritina canalis is found under stones in riffles within $1-2 \mathrm{~km}$ of the sea, and has a range that extends from the Philippines to the Marquesas (Haynes, 2001). Neripteron dilatatus is able to tolerate relatively high salinities (Liu and Resh, 1997), but has only been collected from rocky substrate in the estuaries of running streams ranging from the Philippines to the Society Islands (Pointier and Marquet, 1990; Haynes, 2001). If the larvae of these species have developed behaviors for retention in coastal waters, then we would expect to see genetic structure between or even within archipelagos. Conversely, if the larvae are passively dispersed, but have adapted to extend their pelagic duration until they can recruit to freshwater habitat, then we would expect to see little genetic structure across the South Pacific, with relatively frequent long-distance dispersal and gene flow occurring in the direction of the prevailing currents.

\section{Materials and methods}

\section{Sampling and sequencing}

We collected $N$. canalis $(n=202)$ and $N$. dilatatus $(n=151)$ from two or more islands in the West Pacific archipelagos of Vanuatu Fiji, and Samoa, as well as from the Society and Marquesan archipelagos in the Central Pacific (Figure 1 and Table 1). We fixed whole specimens in 95\% ethanol, with the opercula propped open to allow proper preservation. N. dilatatus is not known to be present in the Marquesas (Pointier and Marquet, 1990,

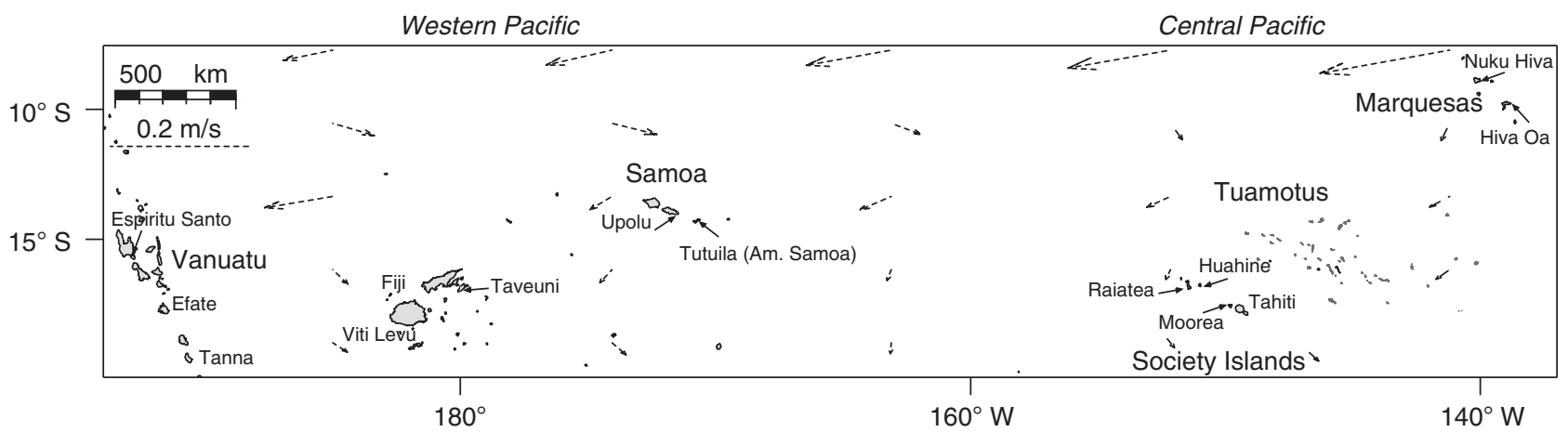

Figure 1 Map of the South Pacific, showing localities sampled in the five archipelagos of high islands. Islands in the Tuamotu archipelago are atolls devoid of running freshwater habitats. The dotted vectors depict a 16-year mean surface currents (Bonjean and Lagerloef, 2002) for the period between October and December, when most Neritid egg cases are hatched (Resh and de Szalay, 1995). 
Table 1 Summary statistics and neutrality test statistics for each island deme shown in Figure

\begin{tabular}{|c|c|c|c|c|c|c|c|c|c|c|c|c|}
\hline \multirow[t]{2}{*}{ Region } & \multirow[t]{2}{*}{ Archipelago } & \multirow[t]{2}{*}{ Island } & \multicolumn{5}{|c|}{ Neritina canalis } & \multicolumn{5}{|c|}{ Neripteron dilatatus } \\
\hline & & & $\mathrm{n}$ & No. of haps & $\mathrm{h}$ & $\pi$ & $\mathrm{F}_{S}$ & $\mathrm{n}$ & No. of haps & $\mathrm{h}$ & $\pi$ & $\mathrm{F}_{S}$ \\
\hline \multirow[t]{7}{*}{ West Pacific } & Vanuatu & Espiritu Santo & & & & & & 19 & 12 & 0.871 & 0.009 & -3.13 \\
\hline & & Efate & & & & & & 23 & 18 & 0.941 & 0.007 & -12.76 \\
\hline & & Tanna & 6 & 6 & 1.000 & 0.004 & -2.86 & & & & & \\
\hline & Fiji & Viti Levu & 17 & 15 & 0.985 & 0.008 & -9.95 & 2 & 2 & 1.000 & 0.012 & NA \\
\hline & & Taveuni & 13 & 10 & 0.970 & 0.005 & -5.05 & 23 & 20 & 0.976 & 0.013 & -11.60 \\
\hline & Samoa & Upolu & 22 & 17 & 0.935 & 0.005 & -14.85 & 23 & 17 & 0.937 & 0.007 & -11.02 \\
\hline & & Tutuila & 24 & 19 & 0.968 & 0.005 & -19.76 & 19 & 11 & 0.889 & 0.008 & -2.52 \\
\hline \multirow[t]{6}{*}{ Central Pacific } & Society Islands & Raiatea & 17 & 11 & 0.912 & 0.005 & -6.11 & 24 & 16 & 0.960 & 0.008 & -7.16 \\
\hline & & Huahine & 18 & 14 & 0.967 & 0.007 & -8.73 & & & & & \\
\hline & & Moorea & 25 & 20 & 0.970 & 0.005 & -21.20 & 18 & 15 & 0.978 & 0.011 & -7.70 \\
\hline & & Tahiti & 18 & 15 & 0.961 & 0.006 & -11.98 & & & & & \\
\hline & Marquesas & Nuku Hiva & 23 & 13 & 0.921 & 0.006 & -5.07 & & & & & \\
\hline & & Hiva Oa & 19 & 12 & 0.924 & 0.006 & -5.53 & & & & & \\
\hline
\end{tabular}

Abbreviation: NA, not applicable.

Haplotype diversity $(h)$, nucleotide diversity $(\pi)$ and $\mathrm{F}_{\mathrm{s}}(\mathrm{Fu}, 1997)$ calculated using Arlequin 3.1 (Excoffier et al., 2005). Significant values of $\mathrm{F}_{\mathrm{s}}(P<0.02)$ are shown in bold.

T Eichhorst, personal communication), and we did not find it there. We extracted genomic DNA from the foot muscle tissue in a $10 \%$ Chelex solution (Walsh et al., 1991). We initially PCR amplified a 658-bp region of mitochondrial cytochrome oxidase I (COI) with standard invertebrate primers, HC0-2198 and LCO-1490 (Folmer et al., 1994). Because these primers amplified with a low success rate $(<50 \%)$, we designed an internal forward primer, NerL (5'-ATGTAATTGTRACTGCTCATGC-3') that amplifies a 520-bp region of the gene, in conjunction with HCO-2198. Reactions occurred in $25 \mu \mathrm{l}$ volumes with $2.5 \mu \mathrm{l}$ of $10 \times$ buffer, $2 \mu \mathrm{l}$ of magnesium chloride $(25 \mathrm{mM}), 2.5 \mu \mathrm{l}$ of deoxynucleotide triphosphate $(8 \mathrm{mM})$, $1.25 \mu \mathrm{l}$ of each $10 \mathrm{~mm}$ primer, $1 \mu \mathrm{l}$ of template and 0.625 units of Amplitaq (Applied Biosystems Inc., Foster City, CA, USA). Thermocycling conditions were: initial denaturation at $94{ }^{\circ} \mathrm{C}(15 \mathrm{~s})$, main cycle at $94{ }^{\circ} \mathrm{C}(30 \mathrm{~s}), 50{ }^{\circ} \mathrm{C}$ (30 s) and $72{ }^{\circ} \mathrm{C}(30-40 \mathrm{~s})$ for $35-39$ cycles, and then a final extension of $72{ }^{\circ} \mathrm{C}(3-10 \mathrm{~min})$. A total of $5 \mu \mathrm{l}$ of successful PCR products were cleaned by adding 0.5 units of shrimp alkaline phosphatase (Biotech Pharmacon, TromsØ, Norway) and five units of Exonuclease I (GE Healthcare, Piscataway, NJ, USA), and incubating at $37^{\circ} \mathrm{C}$ for $30 \mathrm{~min}$ and $80^{\circ} \mathrm{C}$ for $15 \mathrm{~min}$. We sequenced forward and reverse directions of double-stranded PCR products with Big Dye 3.1 terminator chemistry (Applied Biosystems) on an ABI 377 sequencer, and proofread the resulting chromatograms using Sequencher (Gene Codes Corporation, Ann Arbor, MI, USA). Proper translation using the invertebrate mitochondrial code was confirmed using MacClade 4.05 (Maddison and Maddison, 2002).

\section{Data analysis}

We used Arlequin 3.1 (Excoffier et al., 2005) to calculate standard measures of genetic diversity $(h, \pi)$ for each island deme, and also used Fu's $F_{s}(F u, 1997)$, which tests the data for an excess of recent mutations that are indicative of non-neutral processes, such as positive selection or population growth. We then visualized the genetic relationships among haplotypes with a minimum-spanning tree (MST) calculated in Arlequin for each species and then re-drawn by hand using Adobe Illustrator. Each alternative connection identified by the program was evaluated by eye to determine whether it would significantly alter the topology of the MST.

We evaluated hierarchical genetic structure among archipelagos using analysis of molecular variance as implemented in Arlequin 3.1. The data were partitioned into two separate regions: (1) the Western Pacific (Vanuatu, Fiji and Samoa archipelagos) and (2) the Central Pacific archipelagos (Society Islands and Marquesas). We evaluated significance with 10000 random replicates. Pairwise $\phi_{\text {st }}$ among demes was also calculated with 10000 random replicates, and the significance of each value was established after a Bonferroni correction.

Low levels of genetic structure and haplotypes that are shared between distant populations can be explained either by ongoing gene flow over a relatively long period of time or by incomplete lineage sorting after a relatively recent colonization event (Nielsen and Wakeley, 2001). To differentiate between these alternative hypotheses, we used the isolation with migration (IM) program (Hey and Nielsen, 2004) to fit the IM model with the genetic data from the Western and Central Pacific populations of both species. The program uses a Markov chain Monte Carlo methodology to simulate millions of coalescent genealogies while varying the model parameters, comprising time of population splitting $(t)$, migration rates after the populations split $(m / \mu)$, current $\theta$ and ancestral $\theta_{\mathrm{A}}$ $\left(=2 N_{\mathrm{e}} \mu\right)$. The parameter values that are visited most frequently by the program have the highest probability and can be taken as parameter estimates with confidence intervals including $95 \%$ of all values visited by the program. These estimates allow comparison of the model parameters between the two species, assuming that they experience a similar substitution rate. 
The migration rate $\left(N_{\mathrm{e}} m\right)$ is the product of the parameters $m / \mu$ and $\theta$ divided by two. This value summarizes the effective number of migrants per generation that move between the populations after their time of splitting, but does not distinguish between constant migration and a few massive dispersal events. Therefore, because IM explicitly estimates genealogies with migration events between populations, we also used it to produce a histogram of the number of independent migration events inserted during each iteration of the Markov chain (Won and Hey, 2005). To get a heuristic estimate of the maximum amount of time since population divergence, we converted the divergence time, $t$, to years using a relatively slow divergence rate of $1 \%$ per million years (based on fossil-calibrated Molluscan rates, Marko, 2002). Finally, we evaluated differences in population size as the proportion of genealogies for which the $\theta$ value for one population was larger than the other, expressed as a $P$-value.

For both species, we constructed IM data sets that were partitioned between the West Pacific archipelagos (Vanuatu, Fiji and Samoa combined into a single population), and the Society Islands. For $N$. canalis, we constructed a second data set to compare populations from the West Pacific and the Marquesas ( $N$. dilatatus was not present in the Marquesas). After several exploratory runs, we set priors with maximums at $\theta=5000, \theta_{\mathrm{A}}=500, t=5$ and $m=10$, with migration rate in either direction constrained to be equal. We chose an Hasegawa-Kishino-Yano model of mutation over the alternative infinite sites model because several sites included more than one type of substitution. We ran the Markov chains for a minimum of 78 million steps without heating, and a burn-in period of 200000 steps. We determined whether these runs were adequate using effective sample size, which the authors of IM recommend to be $>50$. We replicated runs for each data set at least thrice.

\section{Results}

Mitochondrial COI sequences from $202 N$. canalis contained 117 unique haplotypes (GenBank accession number GU001171-GU001372), whereas 85 unique haplotypes were found in 151 COI sequences from N. dilatatus (GenBank accession number GU001373GU001523). All sequences aligned properly and translated without stop codons, as expected for a coding gene. Three non-synonymous changes were found in $N$. canalis, all of them singletons, and one singleton amino-acid change was found in $N$. dilatatus. Haplotype diversity $(h)$ was high in all demes, with the lowest value for $N$. canalis being 0.912 at Raiatea and the lowest for $N$. dilatatus being 0.871 at Espiritu Santo. Nucleotide diversity was relatively low, ranging from 0.004 to 0.008 in N. canalis and from 0.008 to 0.0013 in N. dilatatus. $\mathrm{Fu}^{\prime} \mathrm{s} \mathrm{F}_{\mathrm{s}}$ values were strongly and significantly negative, indicating departures from the neutral expectations for a demographically stable population for all demes in both species except for two N. dilatatus demes: Espiritu Santo and Tutuila. The results are summarized in Table 1.

Minimum-spanning trees for both species contain star polytomies that are also indicative of processes that cause departures from the neutral model, such as selection or population growth (Slatkin and Hudson,
1991). However, the geographic distribution of this variation differs between species (Figures $2 \mathrm{a}$ and $\mathrm{b}$ ). $N$. canalis shows significant population structure. The central star polytomy contains representatives from all five archipelagos (although haplotypes from the Society Islands and the Marquesas occur at a relatively low frequency), a second polytomy contained only haplotypes from the Society Islands, whereas a third polytomy is almost entirely made up of Marquesan haplotypes (with the exception of one individual from the Societies). Both of these polytomies were rooted at the central polytomy, and none of the 27 alternative connections suggested that they are more closely related to one another. In contrast, the MST topology for $N$. dilatatus shows no evidence of regional structure. The large star topology is dominated by a single central haplotype that was found in 36 snails from all four sampled archipelagos. A few less-frequent haplotypes that are between 2 and $8 \mathrm{bp}$ differences away from the central haplotype are at the center of smaller polytomies.

We qualitatively detected different patterns of genetic structure in the two snail species. Congruent with the patterns observed in the MSTs, we found strong regional structuring between the Western and Central Pacific populations of $N$. canalis, which explained $11.0 \%$ of the genetic variation at the COI locus (Table 2). Regional pairwise $\phi_{\mathrm{ST}}$ values in $N$. canalis revealed no significant structure among the Western Pacific archipelagos of Samoa, Fiji and Vanuatu ( $\phi_{\mathrm{ST}}$ ranging from 0 to 0.02 , no values significant). However, significant structure was detected in pairwise comparisons between these Western Pacific demes and those from the Marquesas and Societies, respectively ( $\phi_{\text {st }}$ ranging from 0.21 to 0.37 , $P<0.0001$, Table 3$)$. In contrast to $N$. canalis, genetic structure in $N$. dilatatus was uniformly non-existent among all archipelagos (global $\phi_{\text {st }}=0.005$, pairwise $\phi_{\text {st }}$ ranging from 0 to 0.04 , no values significant), as suggested by the high degree of haplotype sharing.

Parameter estimates from three replicate IM runs converged to the same or very similar values for data sets from both species (Table 4). Effective sample sizes were all $>75$, and generally $>100$. Trend lines for each parameter indicated that the chain was well mixed. For all three replicate runs of the $N$. dilatatus data set, the posterior distribution for $\theta$ in the Western Pacific archipelagos was not complete before it reached the maximum value of the prior distribution, probably because of high levels of gene flow with unsampled populations to the west (Beerli, 2004).

The isolation with migration model inferred differing rates of gene flow between the Central and Western Pacific in the two species. In $N$. canalis, the $95 \%$ confidence interval (CI) for the migration rates $\left(N_{\mathrm{e}} m\right.$, Table 4) between the West Pacific archipelagos and the Society Islands included the lowest assayed value, and the number of independent migration events reached a modal value at zero, indicating that gene flow in this region is not significantly different from zero in this species. There was a similar result for migration events between the Marquesas and the West Pacific, except that westerly migration events reached their modal value at 2 (95\% CI 0-13), hinting at a small amount of postcolonization gene flow in this direction. In contrast, the migration rate was significantly $>0$ for $N$. dilatatus, and migration events had a modal value of 13 (95\% CI 4-238) 
a
Neritina canalis

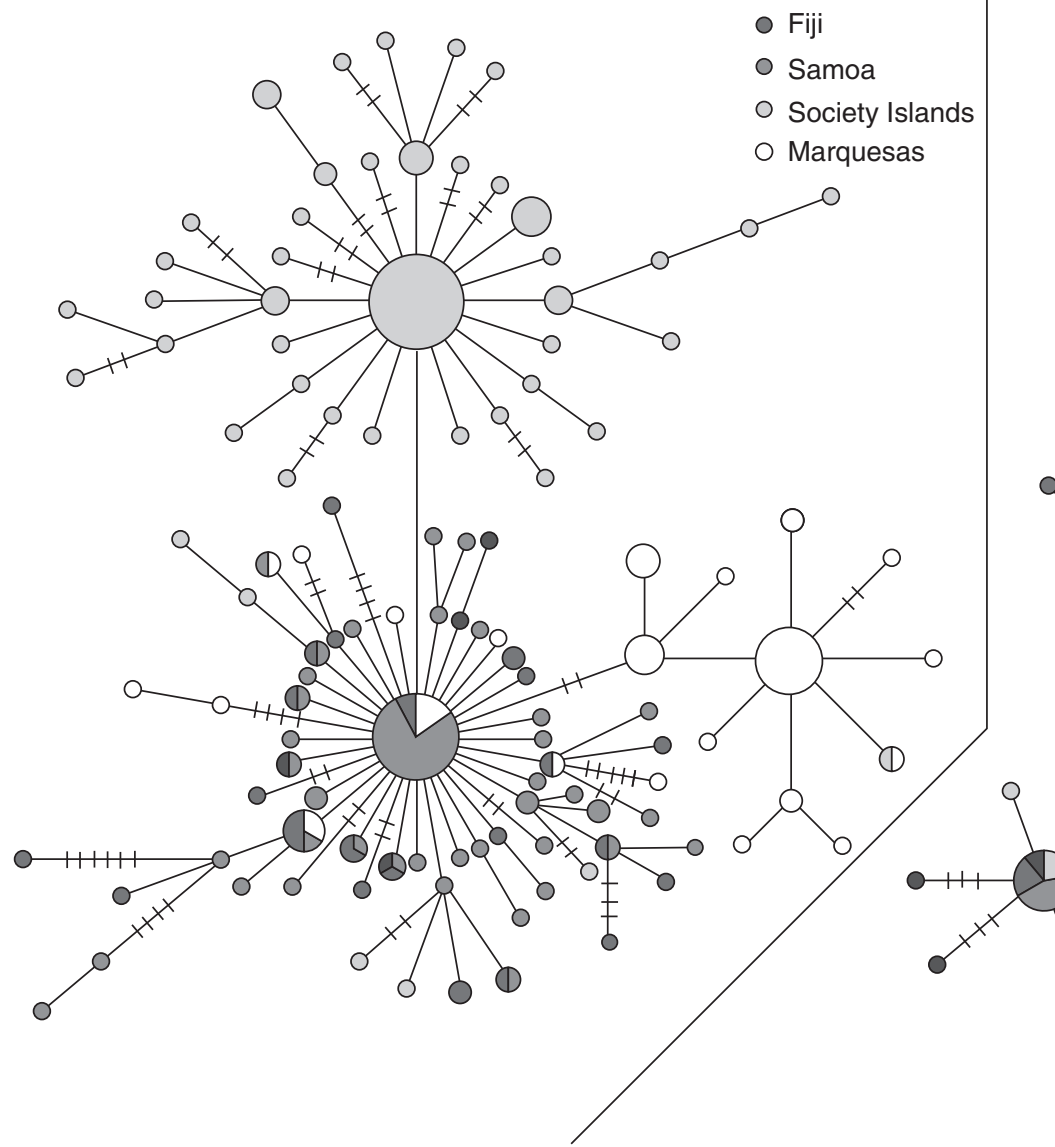

b

Neripteron dilatatus

Figure 2 Minimum-spanning trees (MSTs) for (a) Neritina canalis and (b) Neripteron dilatatus. The circles are sized proportionally to the frequency of occurrence, ranging from 1 to 15 in N. canalis and from 1 to 36 in N. dilatatus. All haplotypes are separated by one mutational step unless denoted by a higher number of hatch marks.

Table 2 AMOVA results for comparisons among West Pacific and Central Pacific regions in both species

\begin{tabular}{lcc}
\hline & $\begin{array}{c}\text { Neritina } \\
\text { canalis }\end{array}$ & $\begin{array}{c}\text { Neripteron } \\
\text { dilatatus }\end{array}$ \\
\hline Overall $\phi_{\mathrm{ct}}$ (between regions) & $\mathbf{0 . 1 1 0}$ & 0.001 (NS) \\
Overall $\phi_{\mathrm{sc}}$ (within regions) & $\mathbf{0 . 2 0 8}$ & 0.004 (NS) \\
& & \\
$\%$ Variation & $10.96 \%$ & $0.13 \%$ \\
Among regions & $18.52 \%$ & $0.38 \%$ \\
Among demes within regions & $70.52 \%$ & $99.48 \%$ \\
\hline Within demes &
\end{tabular}

Abbreviations: AMOVA, analysis of molecular variance; NS, not significant.

The West Pacific region includes Vanuatu, Fiji and Samoan archipelagos. The Central Pacific region includes the Marquesas and Society archipelagos. Significant values in bold indicate a $P<0.05$ after 10000 random permutations of the data.

from the Societies to the West Pacific and 3 (95\% CI 1-191) in the opposite direction (see Supplementary Figure 1).

The Markov chain Monte Carlo simulations suggest that the Western Pacific populations of both species have higher effective population sizes than those in the Central Pacific, as indicated by their consistently larger $\theta$ values $(P<0.02$ in all cases $)$. In addition, $\theta$ values for both contemporary populations of $N$. dilatatus were consistently $>\theta$ for the ancestral population $(P<0.001)$, indicating a significant increase in effective population size in both populations. This was not the case for $N$. canalis, in which $\theta$ values for contemporary populations in both Central Pacific archipelagos were not significantly larger than the ancestral population. Divergence time estimates with a heuristic rate of $1 \%$ per million years indicate that Western Pacific and Society Archipelago populations of $N$. canalis diverged approximately 0.6 million years ago (95\% CI $0.52-1.76$ mya), whereas $N$. dilatatus populations diverged significantly later, approximately 0.3 million years ago (95\% CI $0.22-$ 0.42 mya). The Western Pacific and the Marquesas populations of $N$. canalis diverged approximately 0.4 million years ago (95\% CI 0.28-1.82 mya).

\section{Discussion}

\section{Long-distance dispersal among Western Pacific archipelagos}

Although the adults of both $N$. canalis and $N$. dilatatus occur only in freshwater streams or their estuaries, neither species showed any evidence of genetic structure within or among the Western Pacific archipelagos of Vanuatu, Fiji and Samoa. The simplest explanations for 
Table 3 Pairwise $\phi_{\text {st }}$ values for island demes in Neritina canalis

\begin{tabular}{|c|c|c|c|c|c|c|c|c|c|c|c|}
\hline Locality & 1 & 2 & 3 & 4 & 5 & 6 & 7 & 8 & 9 & 10 & 11 \\
\hline 1. Tanna & 0 & & & & & & & & & & \\
\hline 2. Viti Levu & 0.007 & 0 & & & & & & & & & \\
\hline 3. Taveuni & 0.019 & 0.022 & 0 & & & & & & & & \\
\hline 4. Upolu & 0.010 & 0.017 & 0.018 & 0 & & & & & & & \\
\hline 5. Tutuila & 0.006 & 0.010 & 0.003 & 0.000 & 0 & & & & & & \\
\hline 6. Raiatea & 0.323 & 0.251 & 0.296 & 0.294 & 0.300 & 0 & & & & & \\
\hline 7. Huahine & 0.244 & 0.204 & 0.249 & 0.253 & 0.254 & 0.018 & 0 & & & & \\
\hline 8. Moorea & 0.314 & 0.261 & 0.303 & 0.293 & 0.291 & 0.000 & 0.004 & 0 & & & \\
\hline 9. Tahiti & 0.254 & 0.210 & 0.252 & 0.253 & 0.251 & 0.000 & 0.000 & 0.000 & 0 & & \\
\hline 10. Nuku Hiva & 0.256 & 0.225 & 0.264 & 0.269 & 0.269 & 0.418 & 0.351 & 0.420 & 0.381 & 0 & \\
\hline 11. Hiva Oa & 0.363 & 0.295 & 0.361 & 0.363 & 0.366 & 0.492 & 0.418 & 0.490 & 0.450 & 0.024 & 0 \\
\hline
\end{tabular}

Values in bold were significant after Bonferroni correction for multiple tests (individual $P<0.0009$ ).

Table 4 Mode and 95\% confidence intervals for the parameters of an isolation-with-migration model estimated using IM for Western Pacific (WP) populations (Vanuatu, Fiji and Samoa) and Central Pacific (CP) populations of both species

\begin{tabular}{|c|c|c|c|c|c|c|c|}
\hline & $\theta$ West Pacific & $\theta$ Central Pacific & $\theta$ Ancestral & $\mathrm{t}_{\text {split }}$ & $\begin{array}{c}\mathrm{N}_{e} \mathrm{~m} \\
(C P \rightarrow W P)\end{array}$ & $\begin{array}{l}\text { Westward } \\
\text { migration events }\end{array}$ & $\begin{array}{c}\text { Eastward } \\
\text { migration events }\end{array}$ \\
\hline & \multicolumn{7}{|c|}{ Neritina canalis-Society Islands and Western Pacific } \\
\hline Mode & 0.375 & 0.187 & 0.117 & 0.0033 & 0.49 & 0 & 0 \\
\hline $95 \%$ low & 0.252 & 0.129 & 0.075 & 0.0026 & 0.49 & 0 & 0 \\
\hline \multirow[t]{2}{*}{$95 \%$ high } & 0.967 & 0.310 & 0.456 & 0.0088 & 5.36 & 2 & 1 \\
\hline & \multicolumn{7}{|c|}{ N. canalis-Marquesas and Western Pacific } \\
\hline Mode & 0.725 & 0.060 & 0.122 & 0.0020 & 8.48 & 2 & 0 \\
\hline $95 \%$ low & 0.429 & 0.029 & 0.079 & 0.0014 & 0.94 & 0 & 0 \\
\hline \multirow[t]{2}{*}{$95 \%$ high } & 2.121 & 0.125 & 0.381 & 0.0091 & 40.5 & 13 & 5 \\
\hline & \multicolumn{7}{|c|}{ Neripteron dilatatus-Society Islands and Western Pacific } \\
\hline Mode & 2.582 & 0.322 & 0.071 & 0.0015 & 104 & 13 & 3 \\
\hline $95 \%$ low & 1.341 & 0.168 & 0.041 & 0.0011 & 23.5 & 4 & 1 \\
\hline $95 \%$ high & 9.361 & 1.659 & 0.130 & 0.0021 & 3830 & 238 & 191 \\
\hline
\end{tabular}

Confidence intervals for westerly $N_{\mathrm{e}} m$ are given for the parameter $m$, conditional on the modal value of $\theta$ for the West Pacific. Time estimates are scaled by the reciprocal of the per-site mutation rate, $1 / \mu$, and estimates of $\theta$ are per site.

the absence of genetic structure observed in the Western Pacific are that either both species have maintained high equilibrium levels of gene flow across the Western Pacific $\left(N_{\mathrm{e}} m>10\right.$ migrants per generation) for a long period of time, or that they have undergone a recent range expansion through the region, colonizing each archipelago over a relatively short amount of time. Although our present data are unable to distinguish between these two scenarios, long-distance larval dispersal (that is, dispersal far beyond the mean dispersal distance for these species) must have occurred under both of them.

The velocity of the South Equatorial Current is highly variable, but it generally moves southwest through the study region at average speeds not $>0.07 \mathrm{~m} \mathrm{~s}^{-1}$ (11-year average from Ocean Surface Current Analyses-Real time, http://www.oscar.noaa.gov, Bonjean and Lagerloef, 2002). However, climactic fluctuations can periodically produce much faster current velocities. For example, during the 1999 La Niña event, current velocities in the north of the region reached nearly $0.2 \mathrm{~m} \mathrm{~s}^{-1}$. A veliger larva that is released into the South Equatorial Current during such an event would take about 50 days to cross the $\sim 850 \mathrm{~km}$ of open ocean that separate Samoa from Fiji or Fiji from Vanuatu, if it were to travel in a straight line. The larvae of both species must therefore be able to delay metamorphosis for at least this long to create or maintain the panmixia observed across this region. Similarly, the amphidromous goby Sicyopterus lagocephalus, which is known to have a very long PLD (133-266 days), was found to be panmictic between the Comoros and Mascarene archipelagoes in the Indian Ocean (Hoareau et al., 2007a).

\section{Multiple colonizations of the Central Pacific}

Although both species were genetically homogenous in the Western Pacific, N. canalis showed pronounced structure in the Central Pacific. Significantly smaller $\theta$ values in the relatively young Central Pacific archipelagos (Table 4) suggest that existing populations of $N$. canalis in the Society Islands and the Marquesas are probably the result of two independent, eastward colonization events from the older archipelagos of the Western Pacific. Analysis under the IM model found that, since colonization, no significant gene flow has occurred between the Society Islands population of $N$. canalis and the Western Pacific population, whereas perhaps only a small westward trickle has occurred between the Marquesas and the West Pacific. The haplotypes shared between Central Pacific and Western Pacific populations are thus most likely the result of incomplete sorting of lineages after colonization, and not 
ongoing gene flow. Genetic structure or divergence across the large expanses of open water $(\sim 2000 \mathrm{~km})$ that lie between archipelagos in the Western and Central Pacific, such as what we found in N. canalis, is commonly observed in marine species (Palumbi et al., 1997; Bernardi et al., 2001; Lessios et al., 2001; Crandall et al., 2008) as well as in an amphidromous goby (Keith et al., 2005).

It is therefore remarkable that $N$. dilatatus shows no evidence of genetic structure across this span. There are two possible explanations for this pattern: either one population was recently founded by a massive colonization event from the other population, or else there has been ongoing gene flow between the two populations after colonization. Distinguishing between these two models is a classic problem in population genetics that can be addressed with the IM model (Nielsen and Wakeley, 2001; Hey and Nielsen, 2004). Our IM analyses indicate that the Society Islands population of $N$. dilatatus was probably founded by an eastward colonization event, as indicated by its significantly smaller value for $\theta$. This event occurred no more than 420000 years ago, which is significantly younger than the colonization of the Society Islands by $N$. canalis. However, because IM was unable to reject a model with migration, it is possible that $N$. dilatatus has maintained at least intermittent gene flow across the intervening $\sim 2000 \mathrm{~km}$ of ocean between the Society Islands and Western Pacific populations $\left(N_{\mathrm{e}} m>23.5\right.$ migrants per generation) after this colonization event.

It is interesting to note that IM reckoned a higher number of westerly migration events than easterly events. This indicates that after the inferred eastward colonization event, most of the gene flow in $N$. dilatatus has run westward in the direction of the South Equatorial Current (Table 4). Even at the high speeds estimated for La Niña events $\left(0.2 \mathrm{~ms}^{-1}\right.$, see above), it would take 115 days for the South Equatorial Current to transport a larva from the Society Islands to the Samoan archipelago. The possible difference in gene flow across an area that completely lacks freshwater habitats implies that $N$. dilatatus larvae may be able to delay metamorphosis for longer than the larvae of $N$. canalis, and indeed, most marine species.

\section{Local extinction and recolonization}

Coalescent estimates of population splitting indicate that both species colonized the Central Pacific archipelagos starting no more than 1.82 million years ago, in three independent events. These dates are relatively recent when compared with the geologic age of the oldest island in each archipelago (6 million years in the Marquesas and 10 million years in the Society Islands; Craig et al., 2001). In addition, shallow star polytomies in both MSTs and strongly negative values of $F_{\mathrm{s}}$ in all but two island demes indicate non-equilibrium population dynamics, such as recent population expansions because of colonization (Slatkin and Hudson, 1991; Fu, 1997). Together, these data support a history of local extinctions followed by re-colonization, as has been suggested for other amphidromous species (Cook et al., 2008).

These recent dates of colonization could possibly be explained by an absence of suitable habitat in the Central Pacific archipelagos until about a million years ago, or a low probability of eastward colonization (Paulay and
Meyer, 2002) because of the prevailing westerly currents of the South Equatorial Current. However, decadal current reversals during El Niño events provide a mechanism for occasional colonization events to occur (Bonjean and Lagerloef, 2002; Lessios and Robertson, 2006). Moreover, as islands in these hotspot archipelagos are formed sequentially, they have a large range of ages and therefore offer a wide array of habitats at any one time (Paulay, 1994; Craig et al., 2001). We therefore find it more likely that each of these species has re-colonized the Central Pacific archipelagos after local extinction.

Consistent with this inference, freshwater stream habitats on oceanic islands are known to be inherently unstable at multiple temporal scales. On a decadal scale, individual streams may dry up because of drought, or be scoured by massive floods, causing local extinction of stream populations (Maciolek and Ford, 1987; Resh and de Szalay, 1995, personal observation). Plio-Pleistocene glacial periods resulted in extended periods of decreased rainfall on the Pacific islands, likely drying up streams throughout the region (Hope, 1996). Fluctuating sea levels during this period would have also alternately created and destroyed riverine habitats (Dickinson, 2004). On still deeper timescales, freshwater habitats on oceanic islands undergo substantial change as erosion modifies steeply profiled streambeds into more mature pool and riffle habitats with relatively broad alluvial estuaries. Ultimately, island subsidence reduces adiabatic rainfall to a point where continuous flow cannot be sustained, and riverine habitats are lost (Craig et al., 2001; Craig, 2003).

\section{The evolution of dispersal in amphidromous species}

Species with frequent extinction and recolonization of local populations face two conflicting selective pressures on their dispersal ability (Olivieri and Gouyon, 1997). On one hand, lotic freshwater habitats are rare in the Pacific Ocean, and a larva that recruits to its natal stream should be favored over one that disperses away, as it is unlikely that the dispersive larva will find another stream in which to settle (Strathmann et al., 2002). In contrast, frequent local extinction of stream populations should favor the evolution of larvae that have the ability to delay metamorphosis long enough to find new streams (Holt and Mcpeek, 1996; Elkin and Marshall, 2007). These pressures might not necessarily act in direct opposition. Whereas the former might select for behaviors that favor retention (for example, using chemical cues to stay near natal habitat, Gerlach et al., 2007), the latter might select for developmental and physiological changes that allow for delayed metamorphosis if necessary (as was suggested for habitat specialists in a recent survey of the literature, Bishop et al., 2006).

Although we cannot make any inferences regarding the degree of larval retention with the current data set, our results show that at least some larvae from both amphidromous gastropod species are able to delay larval metamorphosis for longer than many marine species ( $>50$ days in $N$. canalis and $>115$ days in $N$. dilatatus). Other amphidromous species found on oceanic islands have a similarly lengthy PLD (Radtke et al., 2001; Kano, 2006; Hoareau et al., 2007b), an absence of genetic structure across long pelagic distances (Myers et al., 2000; Waters et al., 2000; Hoareau et al., 2007a) and the 
molecular signature of recent colonization events (Myers et al., 2000; Kano and Kase, 2004; Cook et al., 2008). The pelagic larva has only been lost from the life history a few times among the extant freshwater Neritids, and only once in an island species (Holthuis, 1995), even though pelagic larvae have been lost multiple times in other families of marine invertebrates (Duda and Palumbi, 1999; Hart, 2000). Given their unstable habitat, this makes sense, as the evolution of adaptations for larval retention in a freshwater species would lead to its restriction to individual islands and a heightened risk of species extinction (Hansen, 1978; Jablonski and Lutz, 1983).

If instability of lotic habitats on oceanic high islands promotes long-distance larval dispersal, then we should see the opposite pattern in amphidromous species living in continental watersheds. In these geologically older and more stable lotic environments, selection against dispersal from the natal habitat should be unopposed. Consistent with this prediction, phylogeographic studies of amphidromous Atyid shrimp (Page et al., 2005, 2007; Cook et al., 2006) and Galaxiid fishes (Waters and Wallis, 2001) from Australia and New Zealand show evidence for multiple losses of amphidromy, with widespread basal amphidromous lineages giving rise to multiple freshwater lineages that are restricted to watersheds. Within the Neritidae, the only genus with benthic development in fresh water (Theodoxus) occurs in Eurasia (Bunje and Lindberg, 2007), further supporting the prediction that the relative stability of continental riverine habitats supports the loss of planktonic larvae.

\section{Conclusions}

An absence of genetic structure across three archipelagoes in the Western Pacific shows that both N. canalis and $N$. dilatatus have a capacity for long-distance larval dispersal that is as good or better than many marine species. Furthermore, these species have colonized Central Pacific archipelagos that lie over $2000 \mathrm{~km}$ away from the nearest freshwater habitat. Coalescent analysis suggests that these colonization events occurred independently, and relatively recently in comparison with the age of the archipelagos. Predominantly westward gene flow in $N$. dilatatus seems to have continued after colonization, whereas it has more or less ceased in $N$. canalis. Long-lived larvae, and low levels of genetic structure among oceanic island populations of many amphidromous species, combined with the frequent loss of amphidromy in continental watersheds, support theoretical predictions (Johnson and Gaines, 1990; Holt and Mcpeek, 1996; Elkin and Marshall, 2007) that temporal instability of habitats plays a major role in promoting the evolution of dispersal ability.

\section{Acknowledgements}

The idea for this study was originally conceived during the 1998 Biology and Geomorphology of Tropical Islands course, taught at the UC Berkeley Gump Research Station by J Lipps, V Resh and B Mishler, assisted by A Lesen, V Matzek and T Churcher. We gratefully acknowledge the people of Vanuatu, Fiji, Samoa, American Samoa and French Polynesia and their governments for permission to collect in their streams and for invaluable assistance in collecting. In particular, we thank $S$
Gulamhussein, the Turner family, S Ravuna, D Vargo, E Bardi, L Wade, S Siolo, R Utzurrum, K Feussner, M Frey and $\mathrm{N}$ Davies for their assistance in the field. $\mathrm{T}$ Eichhorst provided extensive taxonomic consultation. Field collections were funded by the Conchologists of America (Walter Sage Memorial Fund), American Museum of Natural History (Lerner-Grey Fund) and an NSF DDIG DEB0508788 to EDC. IM analyses were carried out by using the resources of the Computational Biology Service Unit from Cornell University which is partially funded by Microsoft Corporation. Sequencing was funded by NSF OCE-0349177 to PHB. J Finnerty, C Schneider and three anonymous reviewers provided helpful comments on this paper.

\section{Conflict of interest}

The authors declare no conflict of interest.

\section{References}

Anger K, Harms J, Montu M, Debakker C (1990). Effects of salinity on the larval development of a semiterrestrial tropical crab, Sesarma angustipes (Decapoda, Grapsidae). Mar Ecol-Prog Ser 62: 89-94.

Bandel K, Riedel F (1998). Ecological zonation of gastropods in the Matutinao River (Cebu, Philippines), with focus on their life-cycles. Ann Limnol-Int J Lim 34: 171-191.

Beerli P (2004). Effect of unsampled populations on the estimation of population sizes and migration rates between sampled populations. Mol Ecol 13: 827-836.

Benstead JP, March JG, Pringle CM (2000). Estuarine larval development and upstream post-larval migration of freshwater shrimps in two tropical rivers of Puerto Rico. Biotropica 32: 545-548.

Bernardi G, Holbrook SJ, Schmitt RJ (2001). Gene flow at three spatial scales in a coral reef fish, the three-spot dascyllus, Dasyllus trimaculatus. Mar Biol 138: 457-465.

Berrebi P, Cattaneo-Berrebi G, Valade P, Ricou JF, Hoareau TB (2005). Genetic homogeneity in eight freshwater populations of Sicyopterus lagocephalus, an amphidromous gobiid of La Reunion Island. Mar Biol 148: 179-188.

Bishop CD, Huggett MJ, Heyland A, Hodin J, Brandhorst BP (2006). Interspecific variation in metamorphic competence in marine invertebrates: the significance for comparative investigations into the timing of metamorphosis. Int Comp Biol 46: 662-682.

Blanco JF, Scatena FN (2005). Floods, habitat hydraulics and upstream migration of Neritina virginea (Gastropoda: Neritidae) in Northeastern Puerto Rico. Caribb I Sci 41: 55-74.

Bohonak AJ, Jenkins DG (2003). Ecological and evolutionary significance of dispersal by freshwater invertebrates. Ecol Lett 6: 783-796.

Bonjean F, Lagerloef GSE (2002). Diagnostic model and analysis of the surface currents in the tropical Pacific Ocean. J Phys Oceanogr 32: 2938-2954.

Brothers EB, Williams DM, Sale PF (1983). Length of larval life in 12 families of fishes at one tree Lagoon, Great Barrier-Reef, Australia. Mar Biol 76: 319-324.

Bunje PME, Lindberg DR (2007). Lineage divergence of a freshwater snail clade associated with post-Tethys marine basin development. Mol Phylogenet Evol 42: 373-387.

Bunn SE, Hughes JM (1997). Dispersal and recruitment in streams: evidence from genetic studies. J N Am Benthol Soc 16: 338-346.

Chubb AL, Zink RM, Fitzsimons JM (1998). Patterns of mtDNA variation in Hawaiian freshwater fishes: the phylogeographic consequences of amphidromy. J Hered 89: 8-16.

Cook BD, Baker AM, Page TJ, Grant SC, Fawcett JH, Hurwood DA et al. (2006). Biogeographic history of an Australian 
freshwater shrimp, Paratya australiensis (Atyidae): the role life history transition in phylogeographic diversification. Mol Ecol 15: 1083-1093.

Cook BD, Pringle CM, Hughes JM (2008). Molecular evidence for sequential colonization and taxon cycling in freshwater decapod shrimps on a Caribbean island. Mol Ecol 17: 1066-1075.

Covich A (2006). Dispersal-limited biodiversity of tropical insular streams. Pol J Ecol 54: 523-547.

Cowen RK, Lwiza KMM, Sponaugle S, Paris CB, Olson DB (2000). Connectivity of marine populations: open or closed? Science 287: 857-859.

Craig DA (2003). Geomorphology, development of running water habitats, and evolution of black flies on Polynesian islands. Bioscience 53: 1079-1093.

Craig DA, Currie DC, Joy DA (2001). Geographical history of the central-western Pacific black fly subgenus Inseliellum (Diptera: Simuliidae: Simulium) based on a reconstructed phylogeny of the species, hot-spot archipelagoes and hydrological considerations. J Biogeogr 28: 1101-1127.

Crandall ED (1999). Early life history aspects of amphidromous neritid snails in Moorea, French Polynesia. Berkeley Scientific 3: $98-103$.

Crandall ED, Frey MA, Grosberg RK, Barber PH (2008). Contrasting demographic history and phylogeographical patterns in two Indo-Pacific gastropods. Mol Ecol 17: 611-626.

Dickinson WR (2004). Impacts of eustasy and hydro-isostasy on the evolution and landforms of Pacific atolls. Palaeogeogr, Palaeoclimateol, Palaeoecol 213: 251-269.

Diele K, Simith DJB (2006). Salinity tolerance of northern Brazilian mangrove crab larvae, Ucides cordatus (Ocypodidae): necessity for larval export? Estuar Coast Shelf Sci 68: 600-608.

Diesel R, Schuh M (1998). Effects of salinity and starvation on larval development of the crabs Armases ricordi and A. roberti (Decapoda: Grapsidae) from Jamaica, with notes on the biology and ecology of adults. J Crustac Biol 18: 423-436.

Duda TF, Palumbi SR (1999). Developmental shifts and species selection in gastropods. Proc Natl Acad Sci USA 96: 10272-10277.

Elkin C, Marshall DJ (2007). Desperate larvae: influence of deferred costs and habitat requirements on habitat selection. Mar Ecol-Prog Ser 335: 143-153.

Excoffier L, Laval LG, Schneider S (2005). Arlequin v.3.0: an integrated software package for population genetics data analysis. Evol Bioinformatics Online 1: 47-50.

Folmer O, Black M, Hoeh WR, Lutz R, Vrijenhoek RC (1994). DNA primers for amplification of mitochondrial cytochrome $c$ oxidase subunit I from diverse metazoan invertebrates. Mol Marine Biol Biotechnol 3: 294-299.

Fu Y-X (1997). Statistical tests of neutrality against population growth, hitchhiking and background selection. Genetics 147: 915-925.

Gerlach G, Atema J, Kingsford MJ, Black KP, Miller-Sims V (2007). Smelling home can prevent dispersal of reef fish larvae. Proc Natl Acad Sci USA 104: 858-863.

Hansen T (1978). Larval dispersal and species longetivity in lower Tertiary gastropods. Science 199: 885-887.

Hart MW (2000). Phylogenetic analyses of mode of larval development. Cell Dev Biol 11: 411-418.

Haynes A (2000). The distribution of freshwater gastropods on four Vanuatu islands: Espiritu Santo, Pentecost, Efate and Tanna (South Pacific). Ann Limnol-Int J Lim 36: 101-111.

Haynes A (2001). Freshwater Snails of the Tropical Pacific Islands. The Institute of Applied Sciences, University of the South Pacific: Suva.

Hey J, Nielsen R (2004). Multilocus methods for estimating population sizes, migration rates and divergence time, with applications to the divergence of Drosophila pseudoobscura and D. persimilis. Genetics 167: 747-760.
Hoareau TB, Bosc P, Valade P, Berrebi P (2007a). Gene flow and genetic structure of Sicyopterus lagocephalus in the southwestern Indian Ocean, assessed by intron-length polymorphism. J Exp Mar Biol Ecol 349: 223-234.

Hoareau TB, Lecomte-Finiger R, Grondin HP, Conand C, Berrebi P (2007b). Oceanic larval life of La Reunion 'bichiques', amphidromous gobiid post-larvae. Mar Ecol Prog Ser 333: 303-308.

Hodges MH, Allendorf FW (1998). Population genetics and patterns of larval dispersal of the endemic Hawaiian freshwater amphidromous gastropod Neritina granosa. Pac Sci $\mathbf{5 2}$ 237-249.

Holt RD, Mcpeek MA (1996). Chaotic population dynamics favors the evolution of dispersal. Am Nat 148: 709-718.

Holthuis B (1995). Evolution between marine and freshwater habitats: a case study of the gastropod suborder Neritopsina. $\mathrm{PhD}$ thesis, University of Washington.

Hope G (1996). Quaternary change and the historical biogeography of Pacific islands. In: Keast A, Miller SE (eds). The Origin and Evolution of Pacific Island Biotas, New Guinea to Eastern Polynesia: Patterns and Processes. SPB Academic Publishing: Amsterdam, pp 165-190.

Jablonski D, Lutz R (1983). Larval ecology of marine benthic invertebrates: paleobiological implications. Biol Rev Cambridge Phil Soc 58: 21-89.

Johnson ML, Gaines MS (1990). Evolution of dispersaltheoretical models and empirical tests using birds and mammals. Annu Rev Ecol Syst 21: 449-480.

Kano Y (2006). Usefulness of the opercular nucleus for inferring early development in neritomorph gastropods. J Morphol 267: $1120-1136$.

Kano Y, Kase T (2004). Genetic exchange between anchialine cave populations by means of larval dispersal: the case of a new gastropod species Neritilia cavernicola. Zoologica Scripta 33: 423-437.

Keith P, Galewski T, Cattaneo-Berrebi G, Hoareau T, Berrebi P (2005). Ubiquity of Sicyopterus lagocephalus (Teleostei: Gobioidei) and phylogeography of the genus Sicyopterus in the Indo-Pacific area inferred from mitochondrial cytochrome $b$ gene. Mol Phylogenet Evol 37: 721-732.

Lessios HA, Kessing BD, Pearse JS (2001). Population structure and speciation in tropical seas: global phylogeography of the sea urchin Diadema. Evolution 55: 955-975.

Lessios HA, Robertson DR (2006). Crossing the impassable: genetic connections in 20 reef fishes across the eastern Pacific barrier. Proc Biol Sci 273: 2201-2208.

Liu H-TT, Resh VH (1997). Abundance and microdistribution of freshwater gastropods in three streams in Moorea, French Polynesia. Ann Limnol-Int J Lim 33: 235-244.

Maciolek JA, Ford JI (1987). Macrofauna and environment of the Nanpil-Kiepw River, Ponape, Eastern Caroline Islands. Bull Mar Sci 41: 623-632.

Maddison WP, Maddison DR (2002). MacClade 4.05. Sinauer Associates, Sunderland, MA.

Marko PB (2002). Fossil calibration of molecular clocks and the divergence times of geminate species pairs separated by the Isthmus of Panama. Mol Biol Evol 19: 2005-2021.

Marten A, Brandle M, Brandl R (2006). Habitat type predicts genetic population differentiation in freshwater invertebrates. Mol Ecol 15: 2643-2651.

McDowall RM (2004). Ancestry and amphidromy in island freshwater fish faunas. Fish Fisheries 5: 75-85.

Mcdowall RM, Mitchell CP, Brothers EB (1994). Age at Migration from the Sea of Juvenile Galaxias in New Zealand (Pisces, Galaxiidae). Bull Mar Sci 54: 385-402.

Myers GS (1949). Usage of anadromous, catadromous and allied terms for migratory fishes. Copeia 1949: 89-97.

Myers MJ, Meyer CP, Resh VH (2000). Neritid and thiarid gastropods from French Polynesian streams: how reproduction (sexual, parthenogenetic) and dispersal (active, passive) affect population structure. Freshw Biol 44: 535-545. 
Nielsen R, Wakeley J (2001). Distinguishing migration from isolation: a Markov Chain Monte Carlo approach. Genetics 158: 885-896.

Olivieri I, Gouyon P-H (1997). Evolution of migration rate and other traits: the metapopulation effect. In: Hanski I, Gilpin ME (eds). Metapopulation Biology: Ecology, Genetics and Evolution. Academic Press: San Diego, pp 293-323.

Page TJ, Baker AM, Cook BD, Hughes JM (2005). Historical transoceanic dispersal of a freshwater shrimp: the colonization of the South Pacific by the genus Paratya (Atyidae). J Biogeogr 32: 581-593.

Page TJ, Von Rintelen K, Hughes JM (2007). An island in the stream: Australia's place in the cosmopolitan world of Indo-West Pacific freshwater shrimp (Decapoda Atyidae: Caridina). Mol Phylogenet Evol 43: 645-659.

Palumbi SR, Grabowsky G, Duda T, Geyer L, Tachino N (1997). Speciation and population genetic structure in tropical Pacific Sea urchins. Evolution 51: 1506-1517.

Paulay G (1994). Biodiversity on Oceanic Islands-its origin and extinction. Am Zool 34: 134-144.

Paulay G, Meyer CP (2002). Diversification in the tropical Pacific: comparisons between marine and terrestrial systems and the importance of founder speciation. Integr Comp Biol 42: 922-934.

Pointier J, Marquet G (1990). Taxonomy and distribution of freshwater mollusks of French Polynesia. Venus Jpn J Malacol 49: 215-231.

Price JP, Clague DA (2002). How old is the Hawaiian biota? Geology and phylogeny suggest recent divergence. Proc $R$ Soc London B Biol Sci 269: 2429-2435.

Radtke RL, Kinzie RA, Folsom SD (1988). Age at Recruitment of Hawaiian Fresh-Water Gobies. Environ Biol Fish 23: 205-213.

Radtke RL, Kinzie RA, Shafer DJ (2001). Temporal and spatial variation in length of larval life and size at settlement of the Hawaiian amphidromous goby Lentipes concolor. J Fish Biol 59: 928-938.

Resh VH, de Szalay FA (1995). Streams and rivers of Oceania. In: Cushing CE, Cummins KW, Minshall GW (eds). Ecosystems of the World 22: River and Stream Ecosystems. Elsevier: Amsterdam, pp 717-739.

Schneider DW, Frost TM (1986). Massive upstream migrations by a tropical fresh-water Neritid snail. Hydrobiologia 137: $153-157$.
Shanks AL, Grantham BA, Carr MH (2003). Propagule dispersal distance and the size and spacing of marine reserves. Ecol Appl 13: S159-S169.

Slatkin M, Hudson RR (1991). Pairwise comparisons of mitochondrial DNA sequences in stable and exponentially growing populations. Genetics 123: 603-613.

Smith GC, Covich AR, Brasher AMD (2003). An ecological perspective on the biodiversity of tropical island streams. Bioscience 53: 1048-1051.

Sorensen PW, Hobson KA (2005). Stable isotope analysis of amphidromous Hawaiian gobies suggests their larvae spend a substantial period of time in freshwater river plumes. Environ Biol Fish 74: 31-42.

Sponaugle S, Cowen RK, Shanks A, Morgan SG, Leis JM, Pineda JS et al. (2002). Predicting self-recruitment in marine populations: biophysical correlates and mechanisms. Bull Mar Sci 70: 341-375.

Strathmann RR, Hughes TR, Kuris AM, Lindeman KC, Morgan SG, Pandolfi JM et al. (2002). Evolution of local recruitment and its consequences for marine populations. Bull Mar Sci 70: 377-396.

Thorson G (1950). Reproductive and larval ecology of marine bottom invertebrates. Biol Rev Cambridge Phil Soc 25: $1-45$.

Torres G, Anger K, Gimenez L (2006). Effects of reduced salinities on metamorphosis of a freshwater-tolerant sesarmid crab, Armases roberti: is upstream migration in the megalopa stage constrained by increasing osmotic stress? I Exp Mar Biol Ecol 338: 134-139.

Walsh P, Metzger D, Higuchi R (1991). Chelex 100 as a medium for simple extraction of DNA for PCR-based typing of forensic material. Biotechniques 10: 506-513.

Waters JM, Dijkstra LH, Wallis GP (2000). Biogeography of a southern hemisphere freshwater fish: how important is marine dispersal? Mol Ecol 9: 1815-1821.

Waters JM, Wallis GP (2001). Cladogenesis and loss of the marine life-history phase in freshwater galaxiid fishes (Osmeriformes: Galaxiidae). Evolution 55: 587-597.

Whittaker RJ, Triantis KA, Ladle RJ (2008). A general dynamic theory of oceanic island biogeography. J Biogeogr 35: 977-994.

Won YJ, Hey J (2005). Divergence population genetics of chimpanzees. Mol Biol Evol 22: 297-307.

Supplementary Information accompanies the paper on Heredity website (http://www.nature.com/hdy) 